\title{
Correlations and fault systematics in the Passamaquoddy Bay area, Southwestern New Brunswick
}

\author{
M.J. McLeod \\ Department of Natural Resources, P.O. Box 1519, Sussex, New Brunswick EOE 1P0 \\ and \\ N. Rast \\ Department of Geological Sciences, University of Kentucky, Lexington, Kentucky 40506 \\ Date Received May 4, 1988 \\ Date Accepted October 1, 1988
}

\begin{abstract}
Three distinct fault-bounded litho-tectonic units have been recognized on Campobello Island in southem Passamaquoddy Bay. These units are the Upper Silurian Wilsons Beach beds, the Lower Silurian Quoddy Formation and the Upper Precambrian Coldbrook Group. Contact relationships between these units and their correlations in the Passamaquoddy Bay area resolve correlation problems between coastal Maine and New Brunswick, and demonstrate the nature of the junction between the Avalon Platform and the Acadian mobile belt. The Wilsons Beach beds are a remnant of the Acadian belt on northeastem Campobello Island, whereas the Coldbrook Group and the Quoddy Formation represent a fault block of the Avalon Platform. The Coldbrook Group, probably overlain unconformably by the Quoddy Formation, plunges to the southwest beneath the Quoddy Formation of southeastem Maine.

The Siluro-Devonian basins formed in a tensional tectonic regime in response to normal(?) faulting. These faults formed along pre-existing zones of crustal weakness that were generated during the late Precambrian by major strike-slip faulting. The present geological configuration of the area was basically established by episodic reactivation of northeast-trending faults (highangle reverse movements) during the compressional regime of the Acadian Orogeny.
\end{abstract}

On reconnaît trois unités litho-tectoniques bordées par des failles sur l'île de Campobello dans lề sud de la baie-de Passamaquoddy. Ce sont les lits de Wilson Beach (Silurien supérieur), la Formation de Quoddy (Silurien inférieur) et le Groupe de Coldbrook (Précambrien supérieur). La corrélation de ces unités et de leurs contacts dans la baie de Passamaquoddy résout les problèmes de corrélation entre la côte du Maine et le Nouveau-Brunswick et démontre la narure de la jonction entre la PlateForme d'Avalon et la ceinture mobile acadienne. Les lits de Wilson Beach sont un résidu de la ceinture acadienne sur le nordest de l'île de Campobello. Par contre, le Groupe de Coldbrook et la Formation de Quoddy représentent un bloc faillé de la PlateForme d'Avalon. Le Groupe de Coldbrook est probablement recouvert avec discordance par la Formation de Quoddy et plonge vers le sud-ouest sous la Formation de Quoddy dans le sud-est du Maine.

I.es bassins siluro-dévoniens se formèrent dans un régime tectonique de tension en réponse à un mouvement normal(?) de failles. Ces failles se créèrent le long de zones de faiblesse crustale déjà établies et issues d'un important coulissement tardiprécambrien. La configuration géologique actuelle de la région s'établit principalement par réactivation épisodique de failles à tendance nord-est (mouvements inverses à fort pendage) durant le régime compressif de l'orogénèse acadienne.

[Traduit par le joumal]

\section{INTRODUCTION}

The Passamaquoddy Bay region of southwestern New Brunswick is an area where it is possible to correlate the rocks of Maine and New Brunswick near the junction of the Avalon Platform (Rast and Stringer, 1974) and the Acadian mobile belt (a term introduced by Rast and Stringer (1974) to denote Paleozoic rocks north of the Avalon Platform that were affected by the Lower Devonian Acadian Orogeny). These correlations have been attempted by Cumming (1967), Ruitenberg (1968), Donohoe
(1978) and Gates (1984). However, the area is extensively faulted; structural and lithological correlations can be made across some faults, but others juxtapose sequences with radically differing geological histories. The complexity is especially great because regional faults trending NE-SW are crossed by later transcurrent faults with NW-SE orientation. Cumming (1967) and Ruitenberg (1967) recognized and mapped the most significant of the latter as the Oak Bay Fault. 
Campobello Island lies in the southwestern part of Passamaquoddy Bay where many of the faults intersect. Here, three distinct fault-bound lithotectonic blocks (McLeod, 1979), have been mapped (Fig. 1): the Wilsons Beach Block containing Upper Silurian rocks, the Quoddy Block containing Lower Silurian and minor Precambrian rocks, and the Coldbrook Block containing Precambrian rocks. The first two blocks are separated by faults oriented NW-SE whereas the third block is separated from the other two by NW- and NE-trending faults.

This paper documents the detailed succession and structure of the rocks exposed on Campobello Island and expands on relationships that establish the Siluro-Devonian history of the Passamaquoddy Bay area. The termination of the Precambrian Avalon Platform in southwestern New Brunswick is also discussed.

\section{LITHOLOGY}

\section{Coldbrook Group}

Most geological maps of Campobello Island (e.g., Ruitenberg, 1968) show it to consist entirely of Silurian rocks. However, Cumming (1967) identified Precambrian rocks in the northeastern portion of Campobello Island. We accept Cumming's suggestion because the rocks he identified as Precambrian are lithologically similar to rocks of the Coldbrook Group of mainland New Brunswick, and are also associated with a distinct, linear aeromagnetic anomaly (Geological Survey of Canada, 1958) that characterizes the rocks of the Avalon terrane on the mainland.

The dominant lithotypes of the Coldbrook Group-equivalents on Campobello Island are light to dark grey, black and pink siliceous tuffaceous rocks and sedimentary rocks that were intruded by numerous deformed and undeformed diabase dykes. Individual units of the volcanic and sedimentary rocks are restricted in distribution, but an almost total lack of complete sequences with discernible bedding, and the abundance of dykes render the establishment of local stratigraphy difficult. Three broadly delineated units (1a-1c, Fig. 1) have been recognized.

Map unit la consists of fine- to medium-grained, tuffaceous sedimentary and fine-grained siliceous tuffaceous rocks, and minor mafic tuffaceous rocks. The tuffaceous sedimentary rocks occur in thin beds $(10 \mathrm{~cm}$ thick) that contain truncated ripple structures and arcuate flaser-like fragments of silt. The finegrained tuffaceous rocks occur in thicker beds $(0.5 \mathrm{~m})$ and are typically massive.

Unit $1 \mathrm{~b}$ is the most widespread unit of the Coldbrook Group on the island and consists of siliceous coarse- to fine-grained lithic and crystal-rich tuffaceous rocks. The thickly bedded $(1 \mathrm{~m})$ coarser types commonly contain siliceous bombs and lapillisized fragments and in places exhibit large-scale cross-bedding, parallel lamination and normal grading. The finer-grained tuffs are similar in composition to the coarse-grained types, but bedding features are very rare.

Fine-grained and completely recrystallized siliceous sedimentary rocks predominate in the third unit (map unit 1c). Minor proportions of similar rocks are also present in the other two units. These rocks lack bedding features, are black in colour, and contain pink and grey blotches oriented parallel to the $S_{1}$ fabric. Recrystallized, fine-grained, siliceous volcanic rocks are locally present. They are spotted with vari-coloured blebs up to $1 \mathrm{~cm}$ in length, that are elongate parallel to the structural trend. These are interpreted to represent disrupted relics of primary layering affected by deformation and metamorphism. Highly sheared and recrystallized felsic breccias also occur in this unit.

\section{Quoddy Formation}

The Quoddy Formation of Campobello Island has previously been recognized (Bastin and Williams, 1914; Cumming, 1967; Ruitenberg, 1968; Gates, 1969), but no attempts were made to describe its lithostratigraphic succession in detail.

The main lithologies of the Quoddy Formation (which is at least $1500 \mathrm{~m}$ thick) on Campobello Island are black to grey siltstone, sandstone, shale and argillite (map unit 2). These lithotypes comprise about $65 \%$ of the stratified rocks in the section. The remaining $35 \%$ (units $2 \mathrm{a}, 2 \mathrm{~b}$, and $2 \mathrm{c}$ ) consists of olive to dark green, mafic volcanic rocks which include hyaloclastite, hyalotuff, flows, agglomerate, pillow lava and tuffaceous rocks. Sub-units in the Quoddy Formation are distinguished on the basis of the relative proportions of these lithologies. Also present in the formation are abundant diabase dykes and gabbro plugs.

The base of the section near the eastern shore of the island (unit $2 \mathrm{a}$ ) is composed predominantly of interbedded basaltic tuffaceous rocks and agglomerate that appear to rest unconformably on the Precambrian rocks. The rocks consist of beds, $10 \mathrm{~cm}$ to $1 \mathrm{~m}$ thick, that are usually fairly homogeneous but are in places normally graded and cross-laminated. The agglomerates consist of varying proportions of highly vesiculated bombs, up to $10 \mathrm{~cm}$ in diameter, embedded in a tuffaceous matrix. Boulders and small outcrops containing pillows have also been observed. The tuffaceous rocks vary in grain size and contain abundant mafic volcanogenic siltstone and sandstone fragments. Similar rocks, in minor amounts, occur sporadically throughout the section.

Siliceous and commonly pyritiferous siltstone, sandstone, shale and argillite occur typically in $10 \mathrm{~cm}$ to $1 \mathrm{~m}$ thick, regularly bedded sequences but are locally much thicker or thinner. These occur throughout unit 2 , and in minor amounts in units $2 a, 2 b$ and 2c. Most exposures contain minor but variable amounts of ash and volcanic fragments similar in texture and composition to nearby basaltic rocks. These constituents suggest an intrabasinal source of this component. Other constituents such as quartz and quartzite fragments were derived from outside the depositional basin. The mafic volcanogenic sedimentary rocks in map unit $2 b$ contain an unusually high percentage of mafic tuffaceous debris.

Individual beds in map unit 2 exhibit many features of turbidite deposits, including: lateral persistence, sharp basal contacts with well developed erosional structures, overall grading from coarse grained at the base to fine grained at the top and combinations of graded, parallel laminated, convolute and ripple laminated units with intervening pelitic layers. Many beds contain $\mathrm{T}_{b-e}, \mathrm{~T}_{a-\infty}$ and $\mathrm{T}_{c-\varphi}$ (Bouma, 1962) turbidite sequences (Fig. 


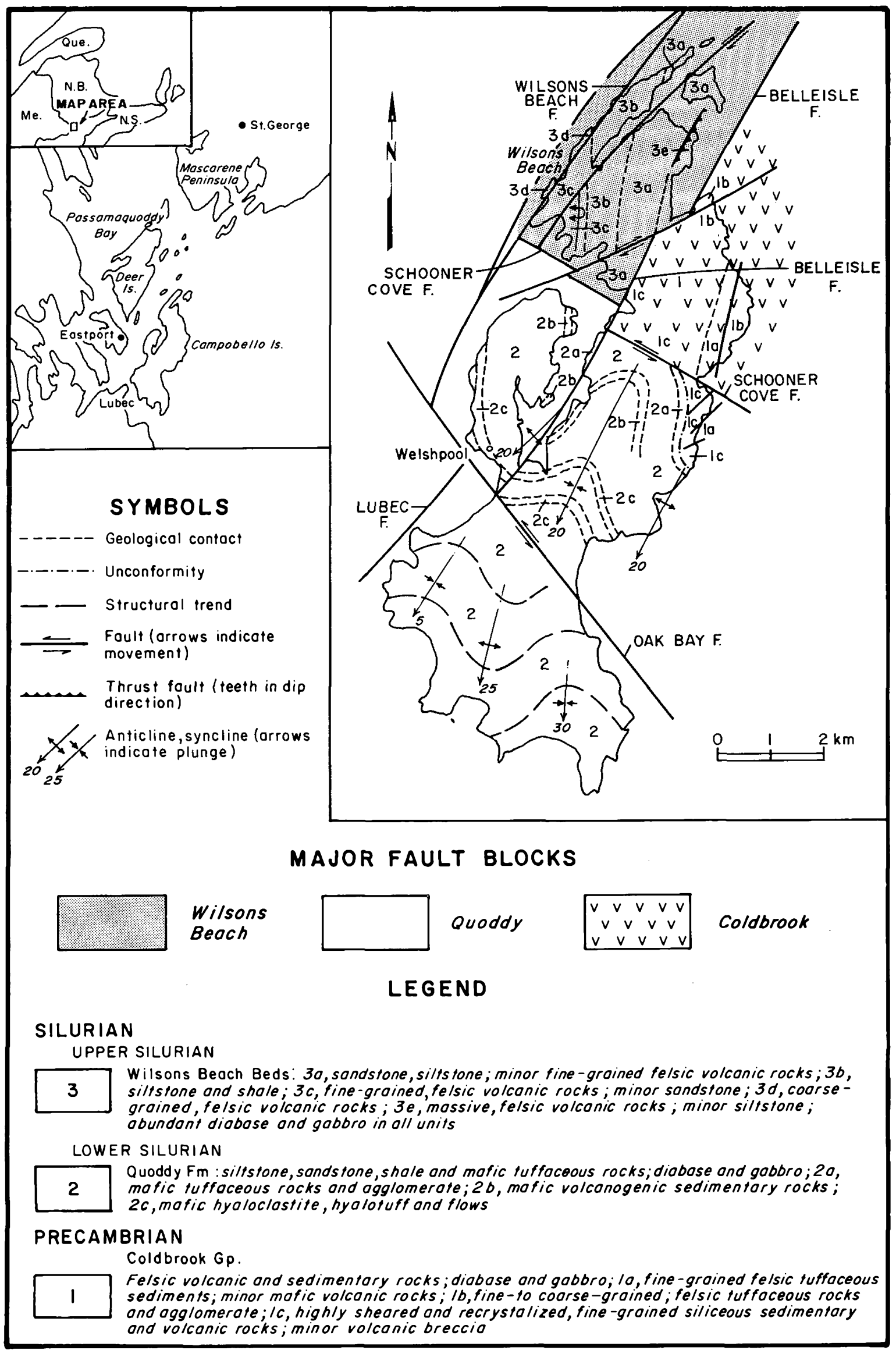

Fig. 1. Geological map of Campobello Island. 
2). A few measurements of erosional structures and of slumps in these rocks indicate sediment transport from the southwest. More detailed investigations of these structures and of facies variations in the Bouma sequences would be required to verify this direction of transport.

Comparison with schemes of turbidite deposition proposed by Walker (1978) and Mutti and Lucchi (1972) indicate that the Quoddy Formation could represent high lower fan or low midfan deposits. R.K. Pickerill (1978, personal communication) suggested that these sediments could have also been deposited on a prodelta slope. Watkins and Boucot (1975) have shown that the fauna in the Quoddy Formation in Maine represent an offshore community. No evidence of near-shore deposits is present in the formation.

Genetically related basaltic hyaloclastites, hyalotuffs and flows also occur in the Quoddy Formation (unit 2c). They are similar to the broken pillow breccias and sideromelane-shard hyaloclastites described by Dimroth et al. (1978). The hyaloclastites, consisting of pillow lavas and pillow breccias, contain highly vesiculated glassy globules, granules and small pillow fragments. The pillow breccias were apparently formed in situ, because they display no evidence of sedimentary transport or compositional heterogeneity typical of conglomerates.

The hyalotuffs occur in thin beds ( 2 to $5 \mathrm{~cm}$ thick) and commonly exhibit parallel lamination and ripple lamination. They consist of either highly vesiculated glassy globules, granules and small pillow fragments or vitric bi- and tricuspate shards and vesiculated bubble wall shards. In conformity with Dimroth et al. (1978) these types are identified as sideromelane-shard and pumiceous hyalotuffs.

At one locality north of Welshpool, a well developed hyaloclastite sequence about $30 \mathrm{~m}$ thick crops out. The sequence begins with a pillow lava, overlain by pillow lava breccia, which is in turn overlain by hyalotuffs (Fig. 3). The sequence ends abruptly and is succeeded by a second hyaloclastite sequence. Laterally, the hyaloclastite and hyalotuff grade into crystal-rich tuffaceous rocks, variolitic tuff and thick (up to $30 \mathrm{~m}$ ) highly vesicular flows.

Hyaloclastites and hyalotuffs are products of subaqueous volcanic activity (Rittman, 1962). The constituents of the hyaloclastites and hyalotuffs on Campobello Island are highly vesicular and angular and were, therefore, following the classification scheme of Honnerez and Kirst (1975), probably deposited in relatively shallow water.

\section{Upper Silurian Rocks}

The thick succession of volcanogenic sedimentary rocks in the Wilsons Beach area, to which a provisional name of the Wilsons Beach beds is assigned, was first recognized by McLeod (1979) as a stratigraphic sequence distinct from the Quoddy Formation because detailed mapping revealed lithological and structural differences.

The Wilsons Beach beds consist mainly of interbedded fineto medium-grained, grey and reddish-grey detrital sedimentary and grey, siliceous, tuffaceous rocks that are at least $850 \mathrm{~m}$ thick. Based on the relative proportion and nature of these rock types, the formation can be divided into three mappable units (3a-3c). Two other units, 3d and $3 \mathrm{e}$, are of unknown stratigraphic position but are provisionally included in the Wilsons Beach beds. The Wilsons Beach beds were also intruded by abundant gabbro plugs.

The base of the first unit (unit 3a) contains dark, relatively massive siltstone. Above this, siliceous siltstone and sandstone occur in fairly thin beds (up to $30 \mathrm{~cm}$ thick) that vary from massive to parallel-laminated,cross-laminated or normally graded. A few thin beds of fine-grained siliceous tuffaceous rock are intercalated with these.

In the upper two-thirds of unit 3a, fine-grained siliceous tuffaceous rocks, siltstone, and minor sandstone predominate. These rocks exhibit bedding features similar to those described above. Toward the top of the unit, other lithotypes occur in minor proportions and include mafic agglomerates, coarser grained siliceous, tuffaceous rocks rich in lithic fragments, and thick (6 $\mathrm{m})$ beds of feldspathic sandstone.

The overlying unit (unit $3 b$ ) is composed mainly of finely laminated and massive siltstone and shale that commonly occur in thin to very thin beds a few $\mathrm{cm}$ thick. Fine intercalations of medium- to fine-grained siliceous tuffaceous rocks and a few thicker coarser grained tuffaceous beds occur within the siltstoneshale unit.

The uppermost unit (unit 3c) of the Wilsons Beach beds resembles the upper portion of the basal unit in that it contains medium and thinly bedded interbedded sequences of fine-grained, siliceous tuffaceous rocks, siltstone, and sandstone. Some of these beds show parallel or cross laminations as well as grading. As in other units of the Wilsons Beach beds, recrystallization has obliterated most primary structures. Fine-grained siliceous tuffaceous rocks are more abundant in this unit than in the basal unit and commonly occur in thicker, more uniform beds.

Units $3 \mathrm{~d}$ and $3 \mathrm{e}$ are fault-bounded and are only tentatively assigned to the Wilsons Beach beds. Map unit $3 \mathrm{~d}$ occurs in the northwest and is composed of siliceous, tuffaceous rocks rich in lithic fragments, felsic agglomerate, and grey shale. It is juxtaposed against other units of the Wilsons Beach beds by the major northeast-trending Wilsons Beach Fault (Fig. 1).

In the southeast, map unit $3 \mathrm{e}$, composed of massive vesicular siliceous volcanic rocks and grey siltstone, has been thrust over the basal part of the Wilsons Beach beds (Fig. 1). The thrust dips shallowly towards the southeast.

\section{Mafic Intrusions}

All three major lithostratigraphic units on Campobello Island were intruded by voluminous mafic rocks that are tholeiitic in chemical character (McLeod, 1979). The Quoddy Formation contains at least two generations of large uralitized gabbroic plugs and two generations of uralitized diabase dykes. The dykes trend approximately $20^{\circ}$ and dip steeply east. Even though these mafic rocks are not penetratively deformed, they are interpreted to have been intruded prior to deformation of the Quoddy Formation, as was suggested by Gates (1977) for similar intrusions in Maine which were penecontemporaneous with deposition of the Quoddy Formation. 


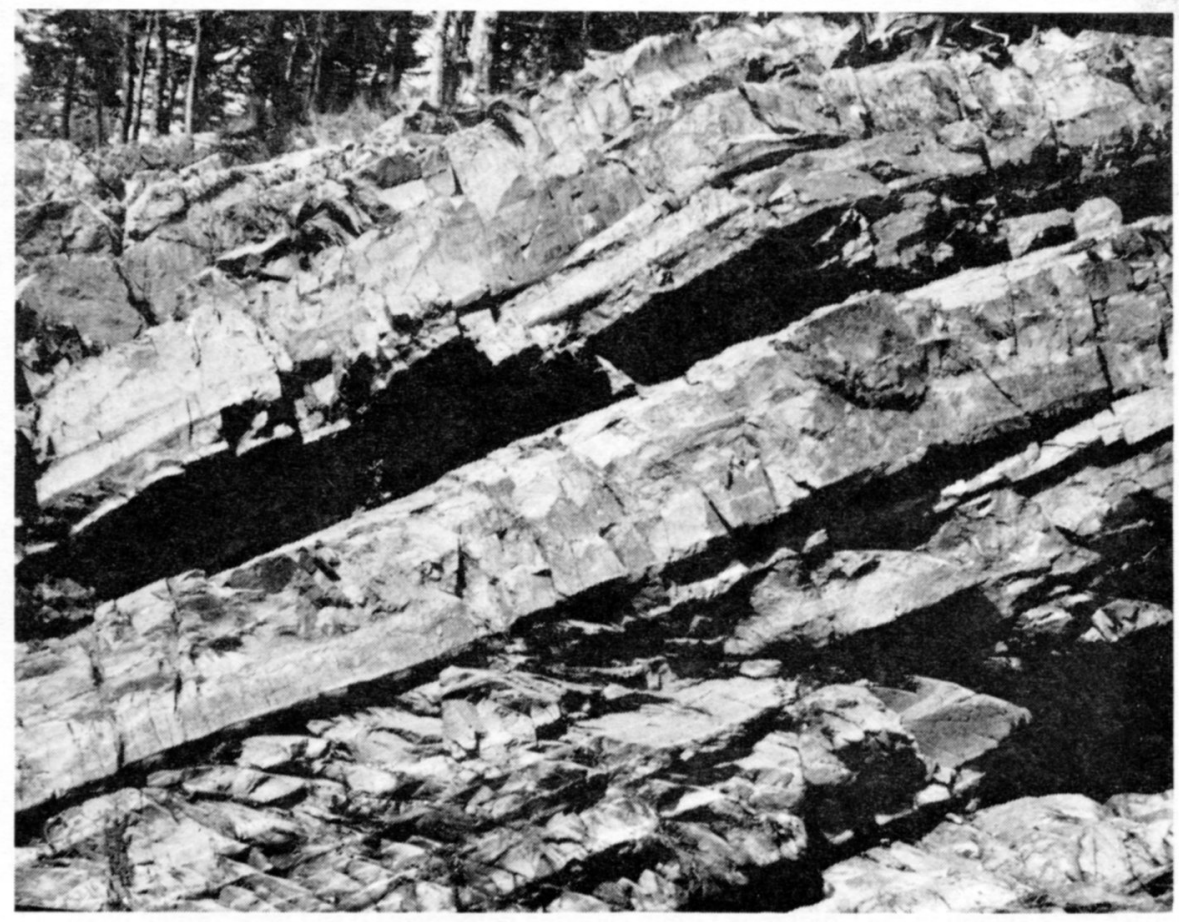

Fig. 2. Turbidite sequences in the Quoddy Formation, Unit 2. $(1 \mathrm{~cm}=0.5 \mathrm{~m})$

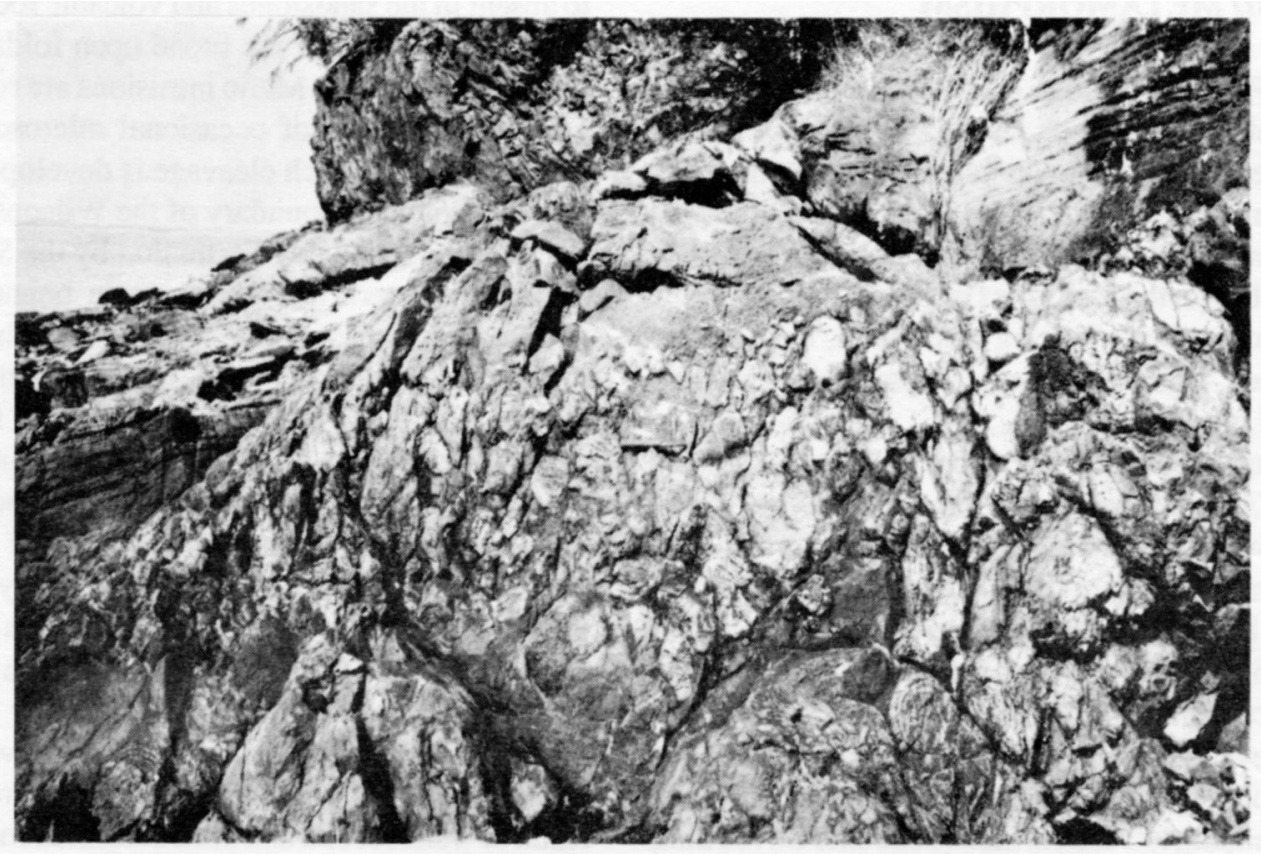

Fig. 3. Hyaloclastite sequence in the Quoddy Formation, Unit $2 c .(1 \mathrm{~cm}=0.5 \mathrm{~m})$

The Precambrian Coldbrook Group was mistaken for the Silurian Quoddy Formation by most previous workers because it also contains similarly oriented mafic dykes (Fig. 4). Although some are massive and identical to those in the Quoddy Formation, many are schistose amphibolites. This evidence suggests that they are of differing ages. No large gabbroic plugs were observed in Coldbrook Group except near the inferred uncon- formable contact with the Silurian units.

Mafic rocks that are intrusive into the Wilsons Beach beds are uralitized gabbroic plugs elongated parallel to the structural trend. Relatively few diabase dykes are present. They vary from deformed and boudinaged to undeformed, suggesting emplacement before and after deformation of the Wilsons Beach beds. 


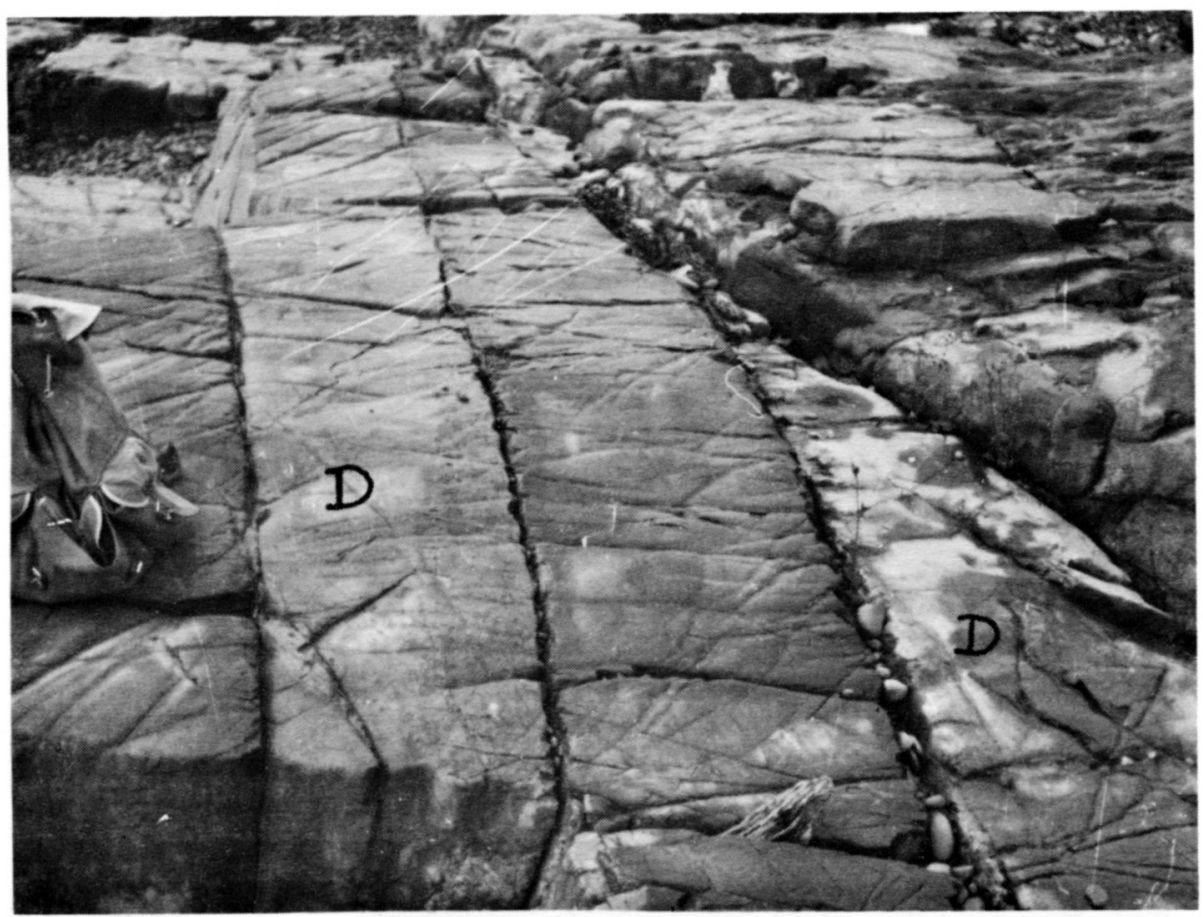

Fig. 4. Diabase dyke swarm in the Coldbrook Group showing deformed(D) and undeformed types. $(1 \mathrm{~cm}=20 \mathrm{~cm})$

\section{STRUCTURE AND METAMORPHISM}

The Belleisle Fault Zone (Fig. 1) locally forms the northwestern boundary of the Coldbrook Group. The lack of visible bedding and the intense recrystallization leaves the major structure of most Precambrian rocks obscure. A few small, nearly isoclinal $F_{1}$ closures that plunge steeply to the southwest were observed. The $S_{1}$ fabric in the rocks is axial planar to these folds. Open folds, that can be seen affecting some beds, have nearly horizontal hinge lines. They are also accompanied by cleavage which may be axial planar.

The well developed $S_{1}$ fabric has a consistent orientation of approximately $30^{\circ} / 70$ south. Along $S_{1}$ planes, well developed mineral and clast lineations plunge steeply to the northeast or rarely to the southwest. Incipient crenulations of $S_{1}\left(F_{2}\right)$ are also widely developed but are typically observable only in thin section. Kinking is presumably related to a third phase of deformation, but is restricted to only the most favorable horizons and then is poorly developed. Orientation of kinks is variable but the dominant direction plunges shallowly towards the north.

A northwest-trending left-lateral fault (Schooner Cove Fault, Fig. 1) cuts across the main outcrop of the Coldbrook Group in the Schooner Cove area. However, just south of the fault, the Quoddy Formation (unit 2a) is inferred to lie unconformably on Precambrian strata and dykes. Farther south the Quoddy Formation is divided into two separate outcrop areas by the Oak Bay Fault (Fig. 1). On the north and south side of the Oak Bay Fault, broad open folds in the formation plunge shallowly towards $215^{\circ}$ and $195^{\circ}$, respectively. The presence of the Oak Bay Fault is established from the differing plunges of these folds as well as the displacement of their axial traces.

Cleavage in the Quoddy Formation varies from weak to well developed in the finer-grained sedimentary rocks and from weak to absent in the sandstones and volcanic rocks. It strikes parallel to the axial planes of the broad open folds but its dip diverges towards fold limbs. Mafic intrusions are relatively undeformed with the exception of occasional microscopic shear zones or larger shears in which cleavage is developed.

The southem boundary of the Wilsons Beach beds is separated from the Quoddy Formation by the Schooner Cove Fault. The northwestern and southeastern boundaries are northeasttrending fault zones--the Wilsons Beach and Belleisle fault zones, respectively. The effects of at least three deformations are present in the Wilsons Beach beds. The first $\left(D_{1}\right)$ produced a major syncline with attendant well developed axial planar cleavage $\left(S_{1}\right)$, related anticlinal structures on both limbs of the syncline, and several minor folds. Some of the mafic intrusions contain the $S_{1}$ fabric. More competent layers in the uppermost units are commonly boudinaged. Fold axes plunge shallowly and vary in azimuth from $010^{\circ}$ to $045^{\circ}$. The western limb of the syncline locally dips steeply eastward or is vertical, but commonly it is overturned, giving the sense of vergence and facing to the northwest. Variations in vergence are interpreted to be a result of weak second and third deformations warping both $S_{0}$ and $S_{1}$. Effects of weak second deformation are observed in some thin sections as a crenulation of $S$, with attendant fracture cleavage. The third phase of deformation formed two sets of kinks in some horizons. The first set consists of kinks that plunge steeply to the northeast or southwest on $S_{1}$ surfaces. This second set is accompanied by fairly pervasive planes resembling crenulation cleavage $\left(S_{2}\right)$ that dip shallowly between north and east.

The Coldbrook Group rocks have been affected by two metamorphic events. The pervasive fabric is accompanied by assemblages indicative of the upper epidote amphibolite to lower amphibolite(?) facies and by intense recrystallization. Epidote hornfelsing overprinted this regional facies assemblage. Meta- 
morphic assemblages in the Quoddy Formation are also indicative of epidote hornfels facies accompanied by complete recrystallization of the matrix. Homfelsing overprinted an earlier greenschist facies regional metamorphic assemblage. The hornfelsing may have been related to emplacement of younger mafic intrusions. The Wilson Beach beds also contain assemblages indicative of greenschist facies metamorphism probably formed during deformation of the Wilsons Beach beds.

The unconformity between the Quoddy Formation and the Coldbrook Group cannot be directly observed because of intense dyking, faulting, and high cliffs in the contact area. However, its presence is indicated by outcrop distributions of the two units, continuity of Silurian mafic intrusions across the contact area, the absence of major faults offsetting the two units, and major differences in structure and metamorphism across the contact. The Coldbrook Group has been affected by intense polyphase deformation accompanied by high-grade metamorphism (at least upper epidote-amphibolite facies) prior to an epidote hornfelsing metamorphic event. In contrast, the Quoddy Formation has been affected by only one deformation accompanied by low-grade metamorphism (greenschist facies) prior to the same epidote hornfelsing event.

\section{REGIONAL CORRELATIONS}

Lithologically, the Coldbrook Group rocks on Campobello Island can be correlated with the Coldbrook Group of the Kingston Zone in southern New Brunswick. Rast and Currie (1976) described a similar zone of Coldbrook Group volcanic rocks intruded by schistose amphibolite dykes just southeast of the Belleisle Fault at Deadman's Harbour. The dykes that they observed were mainly in granitic Precambrian rocks but in places in Coldbrook Group pyroclastic rocks as well. The two zones also show similar deformational features, and the high magnetic response anomaly that characterizes the Coldbrook Group at Deadman's Harbour and to the northeast continues to Campobello Island.

The Coldbrook Group appears to be overlain unconformably by the Quoddy Formation and, thus, disappears down plunge to the southwest. The termination of the high magnetic response anomaly near the inferred unconformity is explained by the combined effects of upthrow on the north side of the Schooner Cove Fault and plunging of Coldbrook Group to the southwest beneath the Quoddy Formation. Farther to the southwest, Precambrian rocks probably underlie portions of the Bay of Fundy and the Gulf of Maine at shallow depths (Ballard and Uchupi 1975).

Sandstone, siltstones and shales in the Quoddy Formation on Campobello Island correlate well with those in the type section for the Quoddy Formation located southwest of Campobello Island at West Quoddy Head, Maine, where fossils and isotopic age data $\left(418 \pm 22 \mathrm{my}\right.$ ) indicate a Llandoverian $\mathrm{C}_{3}$ age (Gates, 1969; Fullagar and Bottino, 1970). Rocks similar to the basaltic volcanic rocks in the Quoddy Formation on Campobello Island are present in the Little River Formation (Cutler and Moose Quadrangles, Maine) of Gates (1961). Fossils collected from the above formation indicated ages which may be "slightly older or younger" than the Quoddy Formation (Gates, 1961). The formation has been more recently assigned to the upper part of the Quoddy Formation (Gates and Moench, 1981). Mafic intrusions in the Quoddy Formation on Campobello Island are petrographically similar to the Cutler diabase which has intruded the Quoddy Formation in Maine. These correlations are restricted to the coastal region of southern Maine, south of the Lubec Fault. Despite contrary claims by Hay (1967) and in accord with Cumming (1967), lithologic equivalents of the Quoddy Formation do not extend to the northeast in New Brunswick and the southern boundary to the formation is unknown.

The Mid-Upper Silurian Letite Formation, described by Donohoe (1978) from the Mascarene Peninsula, is lithologically very similar to the Wilsons Beach beds and the two are at present assumed to be contemporaneous. Structural relationships similar to those found in the Wilsons Beach beds exist northeast of the Belleisle Fault in the Deer Island-Mascarene Peninsula area of New Brunswick (Ruitenberg, 1968; Brown and Helmstaedt, 1970; Brown, 1972; Donohoe, 1978). However, on Campobello Island, second-phase folds are not well developed and do not produce a pervasive second cleavage. The mafic intrusions in this section are also very similar to those found in the Deer IslandMascarene Peninsula area.

\section{SYNTHESIS AND DISCUSSION}

The Passamaquoddy Bay area is essentially composed of three fault-bounded lithologically and structurally distinct zones (Fig. 5). Two of these, the Kingston and Mascarene-Nerepis zones (after Ruitenberg and McCutcheon, 1982) are represented on Campobello Island by the Quoddy-Coldbrook and Wilsons Beach blocks, respectively. The Kingston Zone contains polydeformed Precambrian rocks overlain by the mildly deformed Lower Silurian Quoddy Formation and the Mascarene-Nerepis Zone contains polydeformed Lower to Upper Silurian rocks. The Ovenhead Zone (after Ruitenberg and McCutcheon, 1982), that crops out to the north, contains a gently folded Lower Silurian to Lower Devonian sequence with a locally developed, northeasttrending cleavage non-coplanar to the folds in part. Cumming (1967), Ruitenberg (1968), Pickerill and Pajari (1976), Donohoe (1978), McLeod (1979) and Gates $(1981,1984)$ provided detailed descriptions of the Lower Silurian to Lower Devonian stratigraphy and several authors proposed regional correlations based mainly on faunal evidence, noting structural and lithological contrasts across zones.

Lithological differences between zones in the Passamaquoddy Bay area are easily explained by accumulation of the SilurianLower Devonian rocks as different facies within a large basin(s). Gates (1977) and Pickerill et al. (1978) suggested that these rocks reflect filling of a basin in which fairly deep-water sedimentation, during the Early Silurian, gave way to shallower water and eventually subaerial sedimentation in the Early Devonian. Topographic highs along the northern and southern margin of this basin(s) are represented by Silurian unconformities on Cookson Island (e.g., Ruitenberg, 1967; Gates and Moench, 1981) and Campobello Island (this paper), respectively. Chemical data (Gates and Moench, 1981) indicate that the basin was 


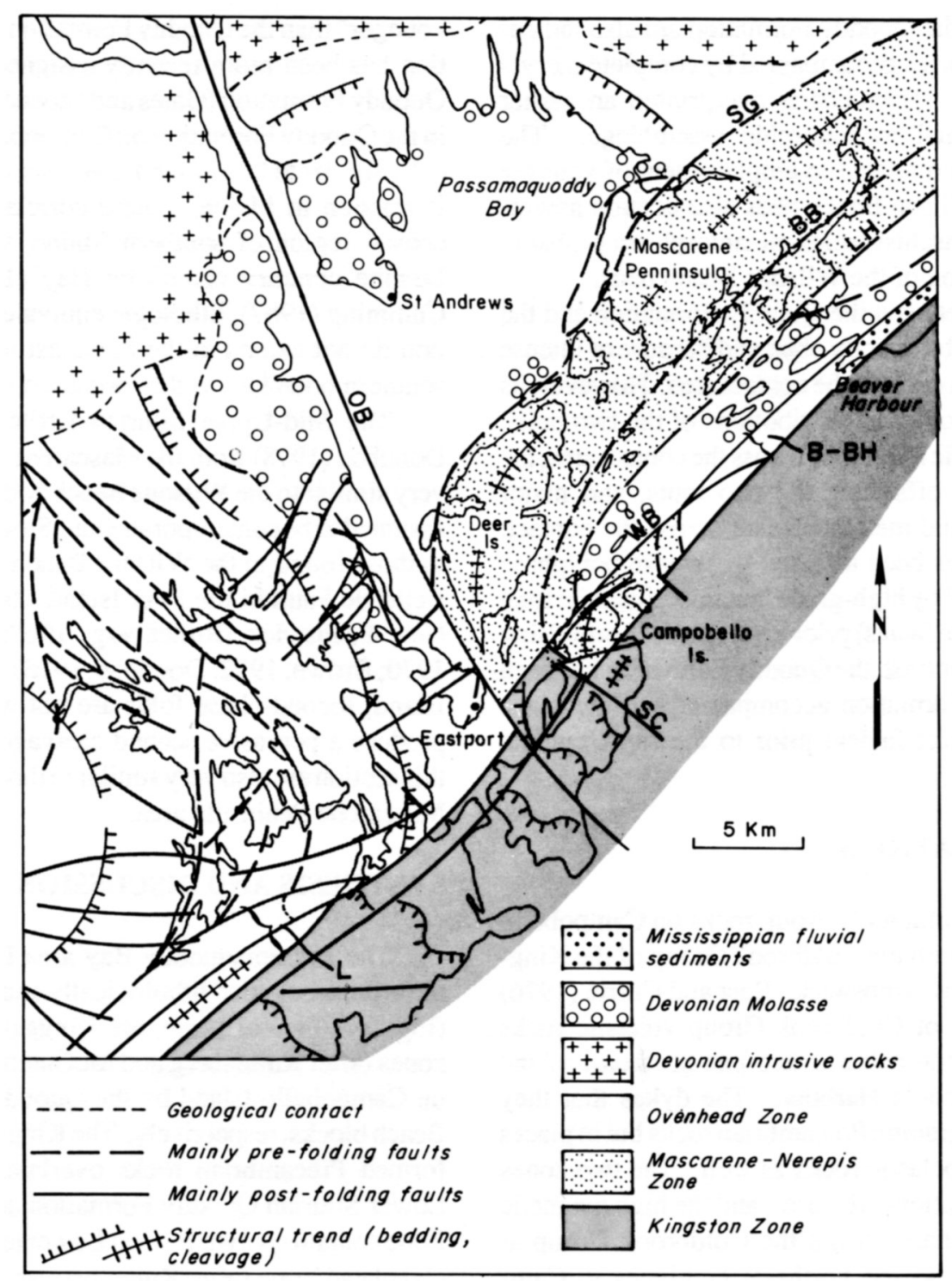

Fig. 5. Distribution of tectonostratigraphic zones in the Passamaquoddy Bay area (New Brunswick geology and zones modified after Ruitenberg and McCutcheon, 1982; Maine geology after Gates, 1982). Fault abbreviations as on Figure 6.

floored by Avalon rocks in a tensional tectonic environment. Rast et al. (1976) and Rast and Currie (1976) indicated the presence of Avalon rocks to the northwest of the Kingston Zone along strike. Currie (1988) has delineated Precambrian granitoid rocks just northeast of St. George within the Mascarene-Nerepis Zone and suggested a similar history of Silurian deposition in that area. Recent gravity studies in New Brunswick (Thomas, personal communication, 1988) and seismic work in Maine (Stewart et al., 1986) also suggest Avalonian-type basement beneath the area.

The authors contend that fundamental structural differences between zones in the Passamaquoddy Bay area necessitates dissociation during the early folding episodes of the Acadian orogeny, during which time the Mascarene-Nerepis and QuoddyKingston zones were deformed by northwest-southeast compression. Deformation of the Ovenhead Zone is not explained by these early events and remains problematical as will be discussed below. An alternative explanation for these differences (Gates, personal communication, 1988), is that the complicated, multiple deformation of the Mascarene-Nerepis Zone is caused by repeated movements along the major northeast-trending faults.

Faults in the Passamaquoddy Bay area lie near the boundary between the Avalon Zone and the Acadian mobile belt (Rast $e t$ al., 1976; Rast, 1979). As demonstrated by Currie (1988), many of these faults undoubtedly utilized pre-existing zones of crustal weakness that developed as mylonite zones in late Precambrian time. The mylonite zones may have formed in response to major strike-slip faulting prior to and during the early stages of the opening of the Iapetus Ocean (Rast and Dickson, 1982). The timing of latest major movement along many of these faults has been established as Late Acadian (e.g., McCutcheon, 1981; Ruitenberg and McCutcheon, 1982; McCutcheon and Robinson, 1987 ) and only minor movement occurred in post-Acadian time. Middle to Upper Devonian intrusions cut these faults andt Carboniferous units can be correlated across these structures (Currie, 1988). 

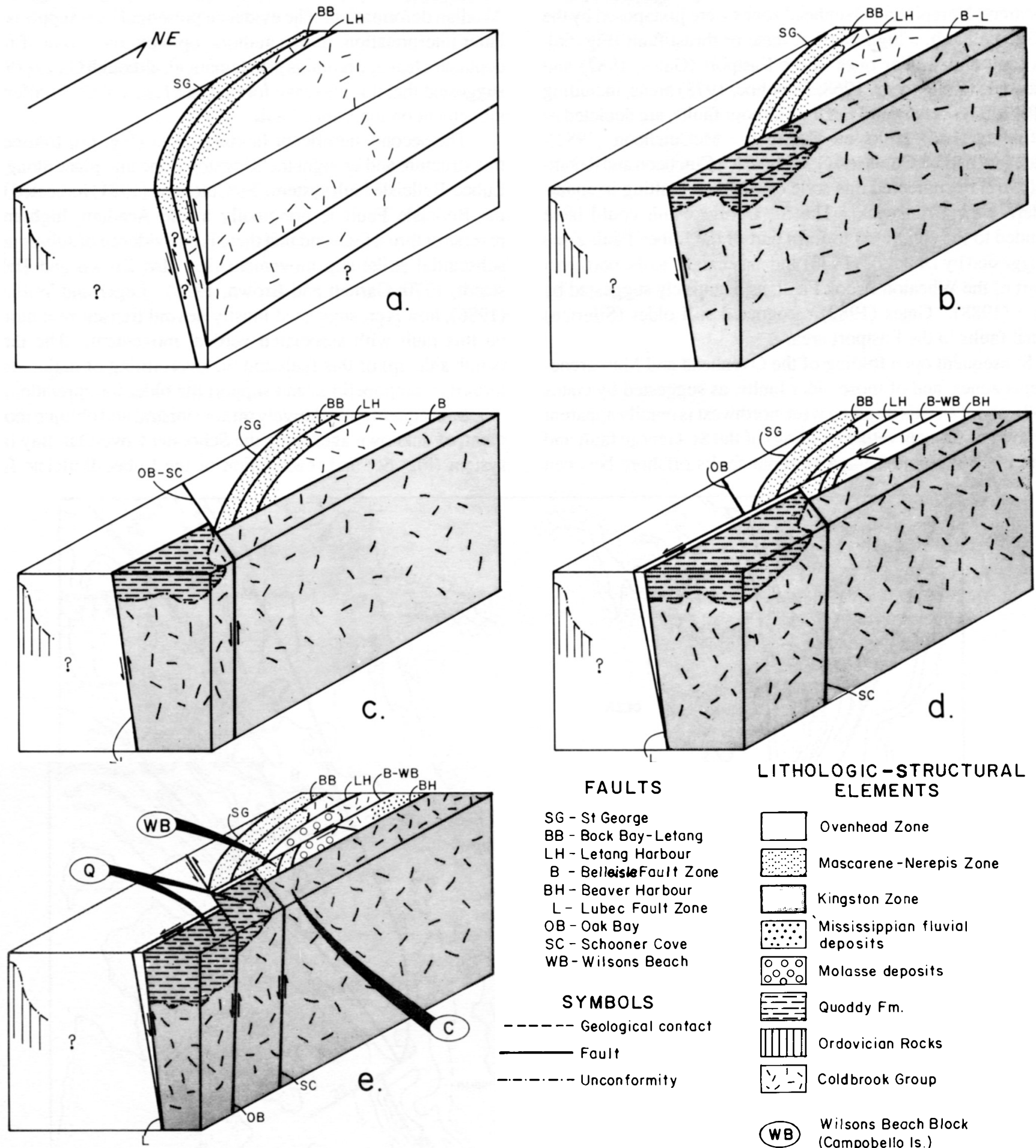

FAULTS

$S G-S \uparrow$ George

BB - Bock Boy-Letang LH - Letang Horbour

$B$ - BelleisleFault Zone $\mathrm{BH}$ - Beover Horbour

$L$ - Lubec Foult Zone OB - Oak Boy

SC - Schooner Cove WB-Wilsons Beoch

SYMBOLS

------ Geological contact

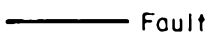

-...-..- Unconformity
LITHOLOGIC - STRUCTURAL ELEMENTS

Ovenheod Zone

Moscorene-Nerepis Zone Kingston Zone

$\because \because$ Mississippion fluvio $\because \because$ deposits

OOOO Molasse deposits

$=$ Quoddy Fm.

[II] Ordovicion Rocks

$\therefore,-1$ Coldbrook Group

Wilsons Beoch Block

(Compobello Is.)

(C) Coldbrook Block (Compobello is.)

(Q) Quoddy Block
(Compobello is.)

Fig. 6. Fault systematics of the Passamaquoddy Bay area. 
A sequence of protracted faulting events is proposed (Fig. 6) togenerate the present geological configuration of Passamaquoddy Bay during the later part of the Acadian orogeny. Initially, the Mascarene-Nerepis and Ovenhead zones were juxtaposed by the St. George Fault, a high-angle reverse or thrust fault (Fig. 6a). This fault and similar ones in the Eastport (Gates, 1982) and Mascarene (Ruitenberg, 1968; Donohoe, 1978) areas, including the Back Bay-Letang and Letang Harbour faults, are depicted as pre-folding (late) faults on Figure 5. McCutcheon (1981), Ruitenberg and McCutcheon (1982) and McCutcheon and Robinson (1987) documented this style of Acadian faulting in southwestern New Brunswick. The St. George Fault could have extended to the southwest to form part of the Lubec Fault Zone as suggested by Donohoe (1978) and may extend to the northeast as part of the Wheaton Brook Fault, as tentatively suggested by Currie (1988). Gates (1982) recognized still older (Silurian) normal faults in the Eastport area.

Subsequent open folding of the Ovenhead and MascareneNerepis zones, and of those older faults, as suggested by Gates (1982), about an axis trending west-northwest is readily apparent on Figure 5. The curvature (folding) of the St. George fault and of the Back Bay and Letang Harbour faults offshore between
Deer and Campobello Islands is evident when water depths are contoured in this area (Fig. 7). This folding event has been attributed to early (Donohoe, 1978) or late (Ruitenberg, 1968) Acadian deformation. The evidence presented here supports the latter interpretation. In the authors' opinion, the origin of noncoplanar cleavage remains problematical, al though Gates (1982) suggested that this cleavage formed as a result of Carboniferous movement on the Lubec Fault.

The second significant faulting event (Fig. 6b) transected this structure and brought the Kingston Zone into place along the Lubec-Belleisle fault system. McCutcheon (1981) indicated that the Belleisle Fault is principally a late Acadian, high-angle reverse or thrust fault and that there is no evidence of subsequent, substantial strike-slip movement (see also Brown and Helmstaedt, 1970; Garnett and Brown, 1973). Leger and Williams (1986), however, suggested mostly dextral transcurrent motion on this fault with associated vertical movement. The throw (south side up) of this fault and the overturning of major structures on Campobello Island support the older interpretation.

Subsequent and relatively minor sinistral and oblique movement, of unknown age, along the Schooner Cove-Oak Bay fault system (Fig. $6 \mathrm{c}$ ) and reactivation of the Lubec-Belleisle fault

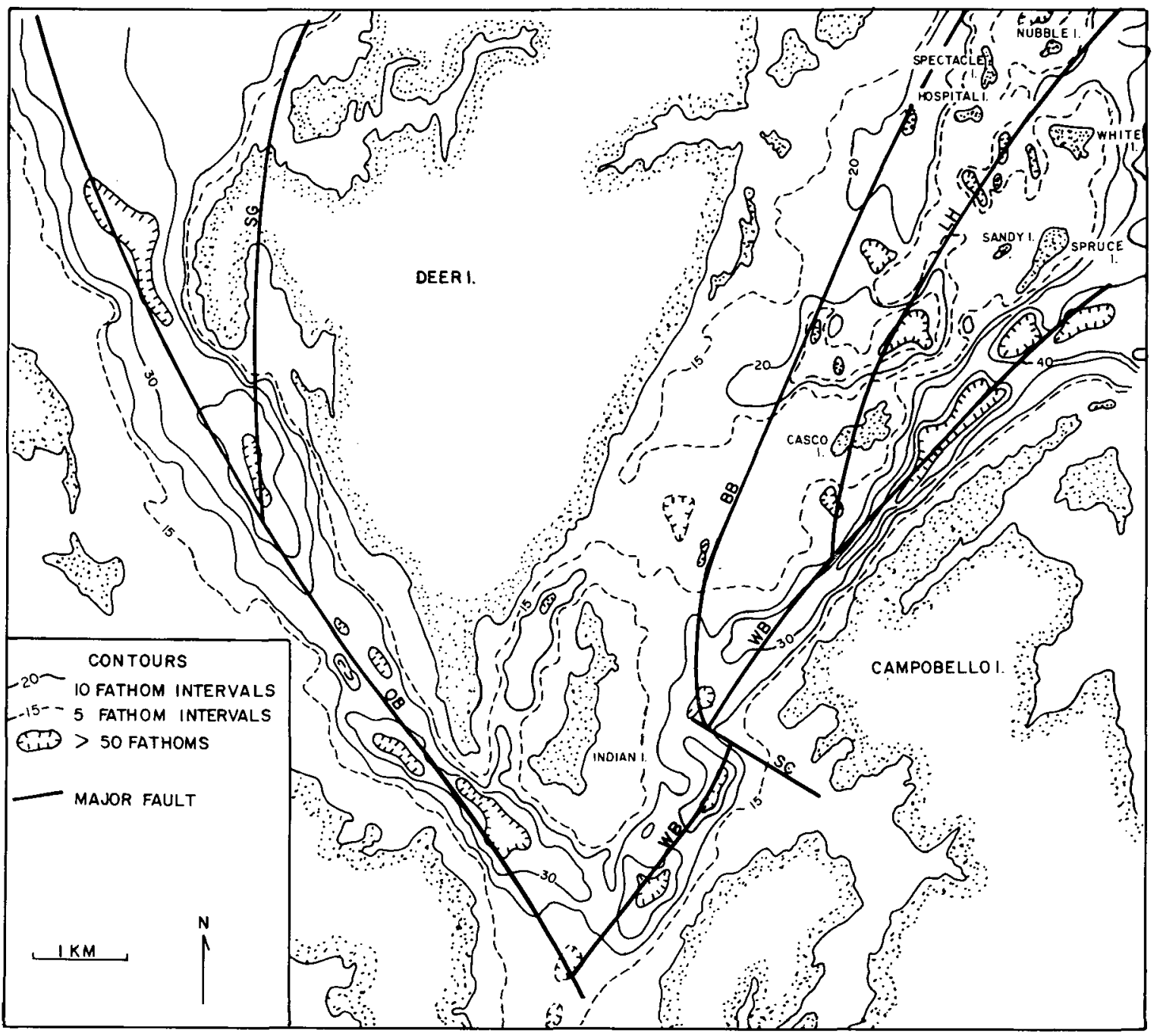

Fig. 7. Contoured hydrographic chart of southem Passamaquoddy Bay. Fault abbreviations as on Figure 6. 
system resulting in minor sinistral of fset (Fig. 6d) established the basic distribution of the major zones in the area. During this event, the southern extension of the Mascarene-Nerepis Zone (the Wilsons Beach beds) was offset left-laterally. These and associated faults (e.g., the Wilsons Beach Fault) are depicted as post-folding faults on Figure 5.

Several of these major faults were reactivated and new, subsidiary faults formed in Late Devonian-Early Carboniferous time as the thickened Acadia crust thinned and extended (Gates, 1982; Ruitenberg and McCutcheon, 1982; McCutcheon and Robinson, 1987) and formed local basins for molasse deposition (Fig. 6e). McCutcheon and Robinson (1987) suggested still later Hercynian thrust movements on these faults, specifically along the St. Gcorge and associated Oak Bay fault systems. Those authors contended that, south of Campobello Island, the Belleisle Fault was offset $50 \mathrm{~km}$ left-laterally along the Oak Bay Fault lineament during Late Acadian and Hercynian time. This conclusion was based mainly on the style of Acadian faulting and on the truncation of magnetic anomalies, indicative of the Kingston Zone and gravity anomalies and partly on work by McLeod (1979). They also indicated that the amount of off set attributable to each event is unknown. Gates (1984) noted this offshore feature but, based on the minor offset along the Oak Bay Fault lineament in Passamaquoddy Bay, cautiously concluded that this could be an old structure active mainly in Precambrian to Cambrian time. Ballard and Uchupi (1975) suggested that the extension of the Oak Bay lineament south of Campobello Island near Grand Manan is part of a basement horst active during Mesozoic rifting in the Gulf of Maine and Bay of Fundy. We suggest that the bulk of the movement referred to be McCutcheon and Robinson (1987) occurred during the Hercynian along the ancestral Oak Bay Fault lineament south of Campobello Island and that, in accordance with McCutcheon and Robinson (1987), this lineament marks the western extent of major Hercynian thrusting. The truncation of geophysical anomalies south of Grand Manan Island undoubtedly reflects this structure but the model suggested here does not necessitate major offset of the Belleisle Fault during Acadian time.

\section{CONCLUSIONS}

The recognition and regional correlation of three distinct, lithotectonic units on Campobello Island, and the analysis of faults bounding these units, clarifies lithological and structural correlation problems in the Passamaquoddy Bay area. The southern part of Campobello Island is underlain by the Lower Silurian Quoddy Formation that occurs south of the Lubec Fault in southeastern Maine. The Precambrian Coldbrook Group occurs on the northeastern part of the Island and is correlative with similar rocks exposed near Deadman's Harbour, New Brunswick, south of the Belleisle Fault Zone. The Quoddy Formation is inferred to lie unconformably on the Coldbrook Group. The plunge of Quoddy Formation and underlying Coldbrook Group to the southwest explains the absence of these units in New Brunswick and Maine, respectively. These units constitute the Kingston tectonostratigraphic zone in southern Passamaquoddy Bay. The Wilsons Beach beds, that occur on north- eastern Campobello Island, correlate with the Upper Silurian Letite Formation of New Brunswick and comprise a segment of the Mascarene-Nerepis tectonostratigraphic zone.

On Campobello Island, the older Silurian rocks (the Quoddy Formation) were only weakly deformed whereas the younger Silurian rocks (the Wilsons Beach beds) were strongly deformed by the Devonian Acadian Orogeny. Precambrian rocks on the island were probably deformed prior to this orogeny. The buttressing effect of the Precambrian rocks beneath the older Silurian rocks provides a possible explanation for this contrast in deformation.

The relatively undeformed Ovenhead Zone and the highly deformed Mascarene-Nerepis Zone, that are in part temporal equivalents, are juxtaposed by faults in northern and western Passamaquoddy Bay. This distribution is explained by invoking folding and reactivation of major Acadian faults trending northeast and northwest.

The Siluro-Devonian basin(s) in this area formed in response to normal(?) faulting near the junction of the Avalon Platform and the Acadian mobile belt. Crustal distension prevailed from the Lower Silurian through the Lower Devonian followed by a compressional regime during the Middle Devonian Acadian orogeny. During this period the basic geological configuration of the Passamaquoddy Bay area was established along major high-angle reverse faults.

\section{ACKNOWLEDGEMENTS}

This paper summarizes some of the results from a M.Sc. thesis on the geology of Campobello Island by M.J. McLeod, supervised by Dr. N. Rast. The encouragement and invaluable advice of Dr. R.K. Pickerill and Dr. G.E. Pajari during the course of this work is gratefully acknowledged. Dr. A.A. Ruitenberg and Dr. O. Gates are thanked for their reading and constructive criticism of the manuscript. The technical services of Mrs. F. Kelly and M. Mazerolle are greatly appreciated.

BALLARD, R.D. and UCHUPI, E. 1975. Triassic rift structure in the Gulf of Maine. Bulletin of American Association of Petroleum Geologists, 59, pp. 1041-1072.

BASTIN, E.S. and WILLIAMS, H.S. 1914. Eastpor folio, Maine. United States Geological Survey, 192, 15 p.

BOUMA, A.H. 1962. Sedimentology of some flyshe deposits. Amsterdam, Elsevier Publishing Company. 168 p.

BROWN, R.L. 1972. Appalachian structural style in southem New Brunswick. Canadian Joumal of Earth Sciences, 9, pp. 43-53.

BROWN, R.L. and HELMSTAEDT, H. 1970. Deformation history in part of the Lubec-Belleisle Zone of southem New Brunswick. Canadian Journal of Earth Sciences, 7, pp. 748-767.

CUMMING. L.M. 1967. Geology of the Passamaquoddy Bay region, Charlotte County, New Brunswick, Canada. Geological Survey of Canada, Paper 65-29, 36 p.

CURRIE, K.L. 1988. Saint George map-area: the end of the Avalon zone in southern New Brunswick. In Current Research, Part. Geological Survey of Canada, Paper 88-1B, pp. 9-16.

DIMROTH, E., COUSINEAU, P., and SANSCHAGRIN, Y. 1978. Structure and organization of Archean subaqueous basalt flows, Rouyn-Noranda area, Quebec, Canada. Canadian Journal of Earth Sciences, 15, pp. 902-918. 
DONOHOE, H.V. 1978. Analysis of structures in the St. George area, Charlotte County, New Brunswick. Unpublished Ph.D. thesis, University of New Brunswick, Fredericton, New Brunswick, 227 p.

FULLAGER, P.D. and BOTTINO, M.I. 1970. Rb-Sr whole rock ages of Silurian-Devonian volcanics from eastern Maine. In Shorter Contributions to Maine Geology. Edited by R.S. Doyle. Bulletin, 23, pp. 49-52.

GARNETT, J.A. and BROWN, R.L. 1973. Fabric variation in the Lubec-Belleisle Zone of southern New Brunswick. Canadian Journal of Earth Sciences, 10, pp. 1591-1599.

GATES, O. 1961. The geology of the Cutler and Moose River Quadrangle, Washington County, Maine. Maine Geological Survey, Quadrangle Mapping Series 1, $67 \mathrm{p}$.

. 1969. Lower Silurian - Lower Devonian volcanic rocks of New England coast and southem New Brunswick. In North Atlantic Geology and Continental Drift. Edited by K. Marshall. American Association of Petroleum Geologists, Memoir 12, pp. 484-503.

- 1977. Geological map and cross sections of the Eastport 15 Quadrangle, Washington County, Maine. Maine Geological Survey, Preliminary Report to accompany Map GM-3, Eastpor, Maine, $19 \mathrm{p}$.

- 1982. Brittle fractures in the Eastport 2-degree sheet, Maine. Maine Geological Survey, Open-File No. 82-29, 15 p.

. 1984. The geology of the Passamaquoddy Bay area, Maine and New Brunswick. Maine Geological Survey, Open-File No. 84-10, $22 \mathrm{p}$.

GATES, O. and MOENCH, R.H. 1981. Bimodal Silurian and Lower Devonian volcanic assemblages in the Machias-Eastport area, Maine. United States Geological Survey, Professional Paper 1184, $32 \mathrm{p}$.

GEOLOGICAL SURVEY OF CANADA. 1958. Aeromagnetic maps 773G (Campobello, 21B/15) and 596G (St. George, 21G/2), scale $=1: 63,360$.

HAY, P.W. 1967. Sedimentary and volcanic rocks of the St. Andrews - St. George area, Charlotte County, New Brunswick. New Brunswick Department of Natural Resources, Mineral Resources Branch, Map Series 67-1, 19 p.

HONNEREZ, J. and KIRST, B. 1975. Submarine basaltic volcanism: morphometric parameters for discriminating hyaloclastites from hyalotuffs. Bulletin Volcanology, 39, pp. 441-465.

LEGER, A. and WILLIAMS, P.F. 1986. Transcurrent faulting history of southern New Brunswick. In Current Research, Part B. Geological Survey of Canada, Paper 86-1B, pp. 111-120.

McCUTCHEON, S.R. 1981. Revised stratigraphy of the Long Reach area, southem New Brunswick: evidence for major, northwestward-directed Acadian thrusting. Canadian Journal of Earth Sciences, 18, pp. 646-656.

McCUTCHEON, S.R. and ROBINSON, P.T. 1987. Geological constraints on the genesis of the Maritimes Basin, Atlantic Canada. In Sedimentary Basins and Basin Forming Mechanisms. Edited by C. Beaumont and A.J. Tankard. Canadian Society of Petroleum Geologists, Memoir 12, pp. 287-297.

McLEOD, M.J. 1979. The geology of Campobello Island, southwestern New Brunswick. Unpublished M.Sc. thesis, University of New Brunswick, Fredericton, New Brunswick, 181 p.

MUTTI, E. and LUCCHI, F.R. 1972. Le torbiditi dell'Appennino settentrionale: Introduzione. all'analisi di facies. (Translated by
T.H. Nilsen, United States Geological Survey, Menlo Park, California). International Geology Review, 20, pp. 125-166.

PICKERILL, R.K. and PAJARI, G.E., Jr. 1976. The Eastport Formation (Lower Devonian) in northern Passamaquoddy Bay area, southwest New Brunswick. Canadian Joumal of Earth Sciences, 13. pp. 266-270.

PICKERILL, R.K., PAJARI, G.E., and DICKSON, W.L. 1978. Geology of Lower Devonian rocks of Passamaquoddy Bay, southwest New Brunswick. In Guidebook for Field trips in Southeastem Maine and Southwestern New Brunswick. Edited by A. Ludman. New England Intercollegiate Geological Conference, 70th Annual Meeting, pp. 38-49.

RAST, N. 1979. Precambrian meta-diabase of southem New Brunswick - the opening of the Iapetus Ocean. Tectonophysics, 59, pp. 127-137.

RAST, N. and CURRIE, K.L. 1976. On the position of the Variscan Front in southem New Brunswick and its relations to Precambrian basement. Canadian Journal of Earth Sciences, 13, pp. 194-196.

RAST, N. and DICKSON, W.L. 1982. The Pocologan mylonite zone. In Major Structural Zones and Faults in Northem Appalachians. Edited by P. St. Julien and J. Beland. Geological Association of Canada, Special Paper 24, pp. 249-261.

RAST, N., KENNEDY, M.J., and BLACKWOOD, R.F. 1976. Comparison of some tectonostratigraphic zones in the Appalachians of Newfoundland and New Brunswick. Canadian Joumal of Earth Sciences, 13, pp. 868-875.

RAST, N. and STRINGER, P. 1974. Recent advances and the interpretation of geological structure of New Brunswick. Geoscience Canada, 1, pp. 15-25.

RITTMAN, A. 1962. Volcanos and their activity. In? Edited by E.A. Vincent. Interscience Publishers, John Wiley and Sons, 72 p.

RUITENBERG, A.A. 1967. Stratigraphy, structure and metallization Piskahegan-Rollingdam area. Leidse Geologische Mededelingen, 40, pp. 79-120.

. 1968. Geological and mineral deposits of the Passamaquoddy Bay area. New Brunswick Department of Natural Resources, Mineral Resources Branch, Report of Investigation 7, 45 p.

RUTTENBERG, A.A., FYFFE, L.R., McCUTCHEON, S.R., St. PETER, C.J., IRRINKI, R.R., and VENUGOPAL, D.V. 1977. Evolution of preCarboniferous tectonostratigraphic zones in the New Brunswick Appalachians. Geoscience Canada, 4, pp. 141181.

RUTTENBERG, A.A. and McCUTCHEON, S.R. 1982. Acadian and Hercynian structural evolution of southern New Brunswick. In Major Structural Zones and Faults in the Northern Appalachians. Edited by P. St. Julien and J. Beland. Geological Association of Canada, Special Paper 24, pp. 131-148.

STEWART, D.B., UNGER, J.D., PHILLIPS, J.D., and GOLDSMITH, R. 1986. The Quebec-western Maine seismic reflection profile: setting and first year results. Reflection seismology: the Continental Crust, Geodynamics Series, 14, pp. 189-199.

WALKER, R.G. 1978. Deep-water sandstone facies and ancient submarine fans: models for exploration for stratigraphic traps. American Association of Petroleum Geologists, Bulletin 62, pp. 932-966.

WATKINS, R. and BOUCOT, A.J. 1975. Evolution of Silurian brachiopod communities along the southeastem coast of Acadia. Geological Society of America, Bulletin 86, pp. 243-254. 